\title{
光学素子作製用ポリシロキサン型電子線レジストの開発†
}

\author{
櫻 井 芳 昭* 佐 藤 和 郎* 福 田宏 輝 ${ }^{*}$ \\ 四谷 任* 鈴 木 義 彦**
}

\section{Development of Polysiloxane Type Electron Beam Resist for Optical Elements}

by

\author{
Yoshiaki SakURA ${ }^{*}$, Kazuo Satoh ${ }^{*}$, Hiroki FukUdA ${ }^{*}$, Tsutom YotsuYa * \\ and Yoshihiko Suzuki ${ }^{* *}$
}

\begin{abstract}
Electron beam lithography is a highly flexible method to fabricate micro-optical elements. However, the long exposure time is the largest problem, which derived from the lack of the sensitivity in electron beam resist. Instead of conventional carbon-based resists, physical properties of polydimethylsiloxane (PDMS) and poly [dimethylsiloxaneco-methylvinylsiloxane] (PMVS) for electron beam were investigated. As a result, these polysiloxanes exhibited a much higher sensitivity of 1.5 and $0.9 \mu \mathrm{C} / \mathrm{cm}^{2}$, respectively and adequate $\gamma$ value of 1.3 . We succeeded in fabricating a four-level computer generated hologram on a glass substrate with ITO film using PMVS in 1/10 exposure time compared with conventional resists.
\end{abstract}

Key words : Electron beam lithography, Electron beam resist, Polysiloxane, Micro-optical element, Computer generated hologram

\section{1 緒 言}

近年になって, IT の発達拡大とともに.回折」現象を 利用した『回折光学素子』の研究, 開発が盛んになって いる. 回折光学素子は, 光の回折効果を利用しレンズ機 能, 分岐/合波, 光強度分布変換, 波長フィルター, 各 種回折パターンの形成に利用できる。 また，一個の回折 光学素子に複数の機能を複合化することができるため小 型軽量な素子設計が可能になり, 量産による光学デバイ スの低コスト化が実現できる.

回折光学素子は従来, 意困する波の状態が得られる格 子構造を導くために膨大な計算量が必要で, またその構 造が導けてもそのような形状に加工できる技術がなかっ たため, 光の特徴を用いた他の光学素子より設計が難し いとされていた，しかし，近年のコンピュータ能力の向 上とナノテクノロジーの発達により, 種々の回折光学素 子の開発が可能になった. 回折光学素子を作製する方法 として, 半導体プロセスを用いる方法 (バイナリーオプ ティクス作製技術）と電子線描画装置を用いる方法が検 討されている. また，電子ビーム描画技術は，サブミク ロンの微細加工性だけでなく, 1 プロセスでの連続階調 ブレーズ（三角）化が可能で, 設計・作製のフレキシビ リティもあり，今後の有望な技術として注目される.1)特 に，バイナリーオプティクス作製技術を用いると，作製 困難な複雑球面を有する微小光学素子 (回折 (フレネル) 型マイクロレンズ）も精度良く作製できる。この電子線 描画法を用いて，光学素子を作製するには，穴の素子の 性能が，用いる電子線レジストに大きく左右され，レジ

\section{ストが“Key”となる.2)}

電子線レジストには, フォトレジストと同じように 「ポジ型」「ネガ型」といった化学反応性の異なるものが ある. ${ }^{3)}$ ポジ型レジストは電子線が照射された部分が化学 反応によって, 現像溶液に溶ける化学構造に変化する (分子量の低下) タイプのレジストである。これに対し て,ネガ型レジストは電子線が照射されていない部分は もともと現像溶液に溶ける性質をもっており, 逆に電子 線が照射された部分が化学反応によって固化し, 現像液 に不溶になったパターンが残るタイプのレジストである. また, 通常, レジストは, ポジ, ネガを問わず, 電子線 を照射するだけで膜表面から基板面まで化学的変化が完 全に生じ, 大きなコントラストを得る（退色効果 (bleaching) が大きいほど画像の解像力がよい) 様に設 計されているデジタル型である (Fig. 1)。デジタル型に 対して, 電子線照射量を変えることにより, 照射量に応 じてレジストの化学的変化をコントロールして, レジス 卜の残膜率を変化させることが可能なアナログ型レジス トが開発されつつある。例えば，多レべル数を有するバ イナリー位相型回折光学素子の微細形状を作製する場合 を考えると，アナログ型レジストを利用すれば作製が容 易であることは明白である。帛の他, 必要なレジスト特 性とは, 感度が高いこと（電子線描画時間の短縮による スループットの向上), ドライエッチング耐性があること （得られたレジスト形状をガラス基板などに転写すること が可能), リソグラフィプロセスに安定であり, 使いやす いレジストであることなどがあげられる。従って，適切

\footnotetext{
$\dagger \quad$ 原稿受理 平成 15 年 3 月 14 日 Mar. 14, 2003

* 大阪府立産業技術総合研究所 †594-1157 和泉市あゆみ野, Tech. Res. Inst. of Osaka Pref., Ayumino, Izumi, 594-1157

** 正会員 大阪府立産業技術総合研究所 ₹594-1157 和泉市あゆみ野, Tech. Res. Inst. of Osaka Pref., Ayumino, Izumi, 594-1157
} 


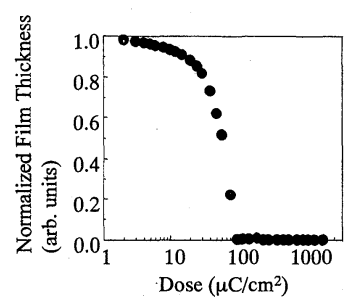

EB EB EB EB

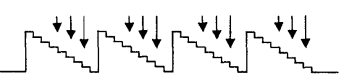

(a)Analogue
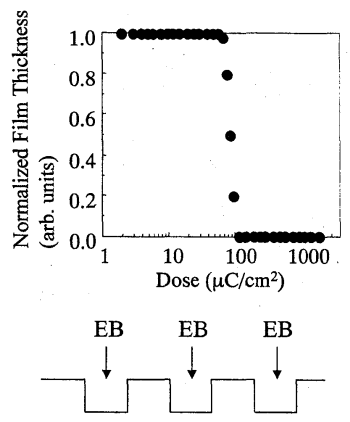

(b)Digital
Fig. 1. Electron beam resist; (a) analogue and (b) digital type.

なレジストを使用し，電子線照射量をうまく制御し描画 を行えば，現像後，ブレーズ（三角形）のような断面形 状を持ったパターンの作製も可能となる。また，マイク ロレンズやホログラフィー素子などの作製も容易になる.

これまで光学素子作製用電子線レジストとして，ポリ メチルメタアクリレート (PMMA) 誘導体が用いられて いるが，感度が高くないことやドライエッチング耐性に 優れないなどの理由で，必ずしも光学素子作製用レジス トとして適しているとは言えない. 市販の他の電子線レ ジストもデジタル型であり, 光学素子作製には不向きで ある。また，現在使用されているレジストは炭素が主成 分であるため，耐エッチング性が不足している。そのた め, より耐エッチング性が高いと期待されるケイ素系の 電子線レジストの開発が望まれている.4)そこで，本論文 では，ケイ素一酸素（シロキサン）結合を有するポリシ ロキサン化合物に焦点をあて，その電子線に対する挙 動・特性の検討を行い，さらに実際のプロセスを行う上 で必要な安定性について調べた結果を述べる。また，本 研究では簡単な光学素子の一例として，電子線描画法に よりポリシロキサンレジストの表面に篞みを生成し，表 面凹凸を用いてホログラムを記録するレリーフ型ホログ ラムを得ることによって 4 位相（フェーズ）レべルの計 算機ホログラム (CGH : Computer Generated Hologram) の作製を行った。

ホログラムは物体光と参照光に実際に干渉を生じさせ， その干渉縞を記録しているものであるが，干渉縞は計算 により求めることができる，従って，計算により求めた 干渉縞を何らかの方法で記録媒体に記録することができ れば，参照光を照射すると物体の再生像が得られること となる。このように計算により求めた光波面の複素振幅 （振幅と位相）の出力を記録したホログラムを CGH と呼 ぶ. CGH は実際に物体が無くても，その再生像が得ら れ，架空の物体の再生やビームの形の制御などに用いら れる，また，ホログラムは複製が難しく，再生するまで 含まれている情報が分からないといった高いセキュリ ティー性を持ち，さらに一部分から再生が可能であるた め, ゴミや傷に強いという特徵を持つ。従って，複雑な CGH を簡便に作製し，製品の管理や偽造防止に応用す ることは非常に有効である.5)

\section{2 実 \\ $2 \cdot 1$ 感度曲線の測定}

験

実験に用いたポリジメチルシロキサン (PDMS) および ジメチルシロキサンとビニルメチルシロキサン $(1$ ～ $2 \%)$ の共重合体 (PMVS) の構造を Fig. 2 に示す.6)PDMS, PMVSの平均分子量 $(\mathrm{Mw})$ はそれぞれポリスチレン換算 で約 400000 ，分散度 (Dp) はそれぞれ約 80 であった。感 度曲線の測定を行うために以下の実験を行った (Fig. 3). PDMS および PMVS をトルエンに $3.5 \mathrm{wt} \%$ 濃度になるよ うに溶解し， Si 基板上にスピンコート法 (2000rpm) で 製膜を行った。その後， $170^{\circ} \mathrm{C}$ のッップレートで 2 分 間プリベークを行い, 膜厚が約 $600 \mathrm{~nm}$ のポリシロキサン 薄膜を得た。この薄膜に，さまざまなドーズ量で $50 \mu \mathrm{m}$ $\times 100 \mu \mathrm{m}$ の矩形の描画を行った。用いた電子線描画装 置は，日本電子株式会社製 JBX-5000SI で，描画は加速 電圧 $50 \mathrm{kV}$ ，電流值 $150 \mathrm{pA}$ で行った。ドーズ量は， 0.7 , $0.8,0.9,1.0,1.3,1.6,2,3.5,6,10,20 \mu \mathrm{C} / \mathrm{cm}^{2}$ て ある.PDMS, PDVS ともに, 描画後, テトラヒドロフラ ン $(\mathrm{THF}):$ ア トニトリル $\left(\mathrm{CH}_{3} \mathrm{CN}\right)=8: 2$ の混合液中に 1 分間浸漬することにより現像を行った。現像後のパター ンの残膜量は，干渉顕微鏡 New-View5020（ZYGO 社製） で測定を行った。

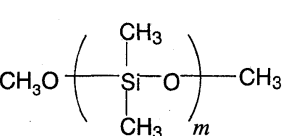

(a)

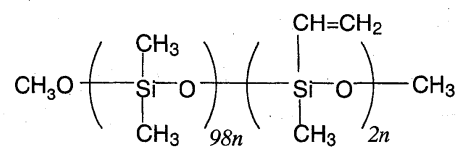

(b)
Fig. 2. Compounds: (a) PDMS, (b) PMVS. (a)

PMVS

(b)

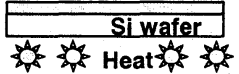

Electron beam

(c)

(d)

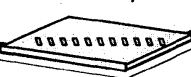

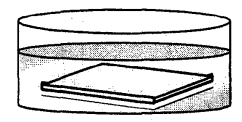

Spincoating of PMVS (1 $\mu \mathrm{m})$

Prebake at $170 \mathrm{C}$

EBL at $50 \mathrm{kV}, 150 \mathrm{pA}$ Changing the time

Development in THF: $\mathrm{CH}_{3} \mathrm{CN}=8: 2$ for $1 \mathrm{~min}$ $50 \times 100 \mu \mathrm{m}$

(e)

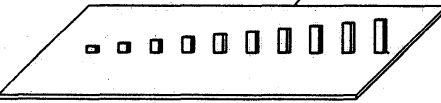

Fig. 3. Measurement for sensitivity of polysiloxanes. The dosage was $0.7,0.8,0.9,1.0,1.3,1.6,2,3.5,6$, $10,20 \mathrm{mC} / \mathrm{cm}^{2}$, starting from the left. 


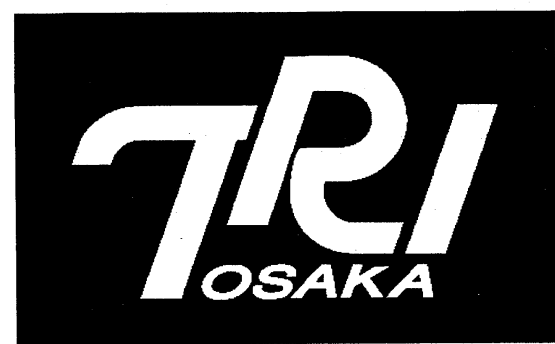

Fig. 4. Target pattern.

\section{$2 \cdot 2$ 光学素子の作製}

Fig. 4 のような再生像が得られる 4 位相（フェーズ） レベルの合成 $\mathrm{CGH}$ (ターゲットパターン）を設計した (TRI は, 当研究所のロゴマーク). ${ }^{7}$ ターゲットパターン は，ピクセルサイズ $10 \mu \mathrm{m} \times 10 \mu \mathrm{m}, 512$ ピクセル $\times 512$ ピクセルからなるフーリエプレーンである. 次に， 4 フ エーズレベルを得るために, 透明 ITO 導電膜付きガラス 基板に膜厚 $1.2 \mu \mathrm{m}$ になるようにPMVS のスピンコートを 行った. その後, 計算機により作製された CGHパター ンに一致するように, 近接効果（レジストの感度の高さ に起因するもので, 電子線が隣接するピクセルに与える 影響）を考慮して, 各ピクセルに電子線照射量を 2.50 , $1.07,0.59,0 \mu \mathrm{C} / \mathrm{cm}^{2}$ と変調させた描画を行った。描画 後, THF : $\mathrm{CH}_{3} \mathrm{CN}=8: 2$ の混合液中に 1 分間浸漬する ことにより現像を行うことで, レジストからなる $\mathrm{CGH}$ を 作製した。

\section{$3 \cdot 1$ ポリシロキサンの感度 \\ 3 結 果 と考 察}

Fig. 5, Fig. 6 は，実験より得られたPDMS および PMVS の感度曲線である. 横軸が電子線照射量, 縦軸が 規格化された残膜率である. Fig. 5, Fig. 6 から電子線 照射量を増加させると残膜率が大きくなることが分かる。 従って, PDMS, PMVS 共にネガ型の電子線レジストで あることが確認できる.

Fig. 5, Fig. 6 から感度 (50\%残膜するドーズ量) とガン マ $(\gamma)$ 值（感度曲線の傾きを表す值）を求めると, PDMS に対しては感度 $1.5 \mu \mathrm{C} / \mathrm{cm}^{2}, \gamma$ 值 1.2 , PMVS に対しては 感度 $0.9 \mu \mathrm{C} / \mathrm{cm}^{2}, \gamma$ 值 1.3 が得られた. 得られた感度は,

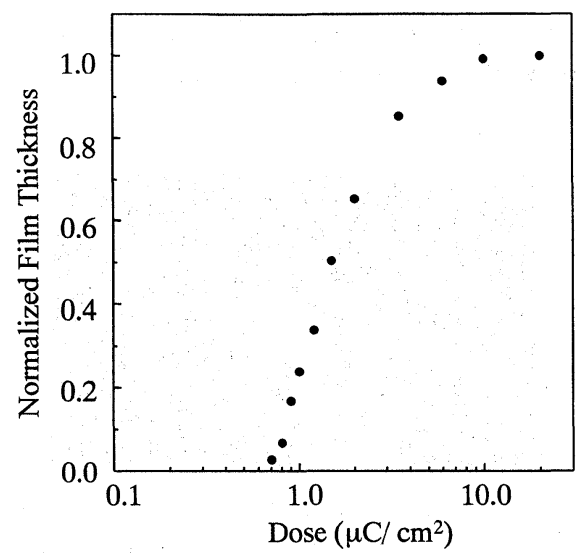

Fig. 5. Sensitivity curve for PDMS.

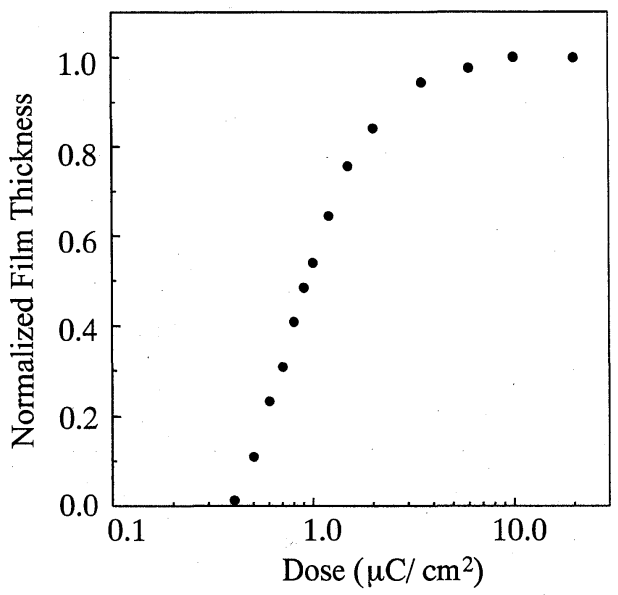

Fig. 6. Sensitivity curve for PMVS.

代表的な電子線レジストである PMMA と比較すると 2 けたほど高い值であった。この高い感度は，シロキサン骨 格中の酸素 $(\mathrm{O})$ 原子の大きな電気陰性度と不対電子に起 因すると考えられる。また，PMVS が PDVSに比べて感 度が高いのは，電子受容性のビニル基によるものである.

電子線描画法を用いて光学素子の作製を考えると, レジ ストの $\gamma$ 值は高すぎる（感度曲線の傾きが大きい, $\gamma>3$ ) と, 電子線照射量を変調させて, 残膜率を制御するのが 困難となる，反対にガンマ值が低すぎる（感度曲線の傾 きが小さい， $\gamma<1 ）$ と, 残膜率を制御するのに必要な電 子線照射量の変調量が大きくなるため, 電子線描画時間 が長くなり，光学素子を作製することが困難となる．実 験結果から得られたPDMS，PMVSの $\gamma$ 值はそれぞれ $1.2 ， 1.3$ であり光学素子を作製するのに適した值である と言える。

\section{$3 \cdot 2$ プロセス安定性}

光学素子の作製プロセスにおいてレジストの安定性が 無ければ，再現性を得るのが困難となり，たとえ性能が 高くても使用しにくいレジストとなる，そこで，PMVS を用いて光学素子の作製プロセスに対する安定性を調心゙ るため，以下の実験を行った。なお，ここではPDMSの 結果は示していないが，ほぼ同じような特性を示した。

Fig. 7 はプリベーク温度が $100^{\circ} \mathrm{C} ， 130^{\circ} \mathrm{C} ， 150^{\circ} \mathrm{C}$ と $170^{\circ} \mathrm{C}$ の PMVS の感度曲線である. Fig. 7 からプリべー ク温度を変化させてもほとんど感度曲線が変化しないこ とが分かる。

Fig. 8 は現像時間が 30 秒, 1 分, 2 分と 5 分の PMVS の感度曲線である.Fig. 8 から現像時間を変化させても ほとんど感度曲線が変化していないことが分かる.

これらの結果から PDMS, PMVSを用いて電子線描画 により光学素子を作製する場合，プロセス管理 (プリベー ク温度や現像時間）をあまり気にしなくても，再現良く 光学素子を作製できることがわかる．また，高い温度の プリベークを行うことのできない材料の基板を用いて光 学素子を作製する場合などでも使用できるレジストであ る。以上のように, PDMS, PMVSともに使いやすい電 子線レジストであると言える。 


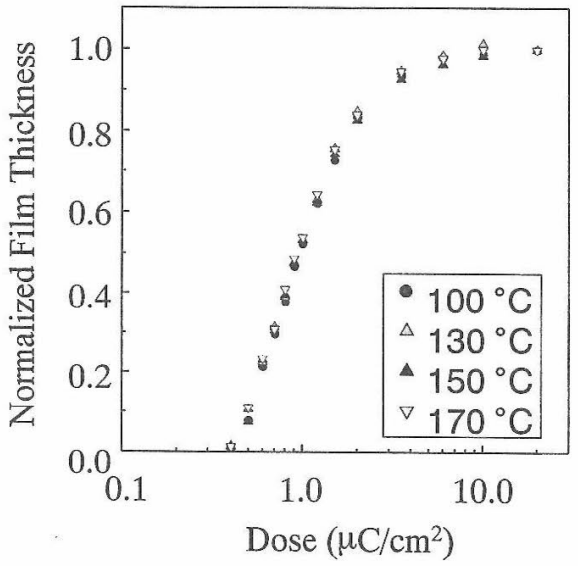

Fig. 7. Electron beam exposure response curves of PMVS with the various prebake temperatures.

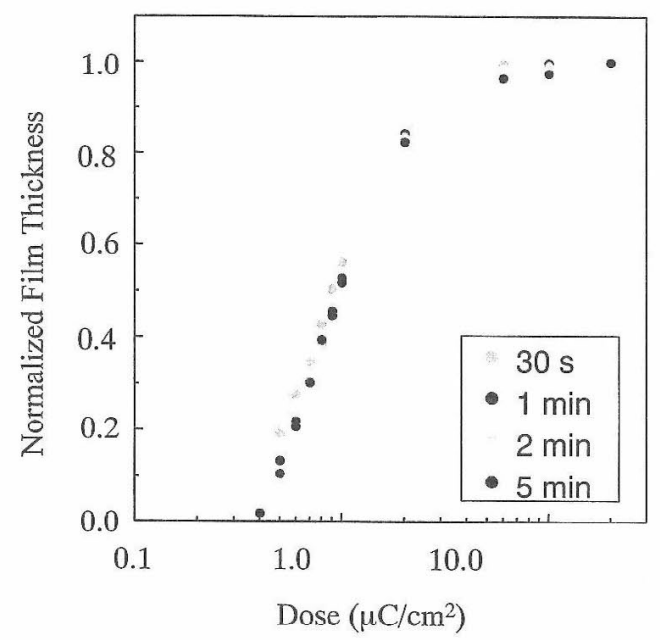

Fig. 8. Electron beam exposure response curves of PMVS with the various developing times.

\section{$3 \cdot 3 \quad \mathrm{CGH}$ の作製}

ターゲットパターンを電子線描画法によりレジストに 記録させるためには，合成 $\mathrm{CGH}$ の作製，合成 CGH のレ ジストへの記録（表面に窪みを生成し，表面四凸を用い てホログラムを記録するレリーフ型ホログラムの作製）を 行うことによって, CGH が得られる. Fig. 9 に反復フー リエ変換アルゴリズムによって 4 位相（フェーズ）レべ
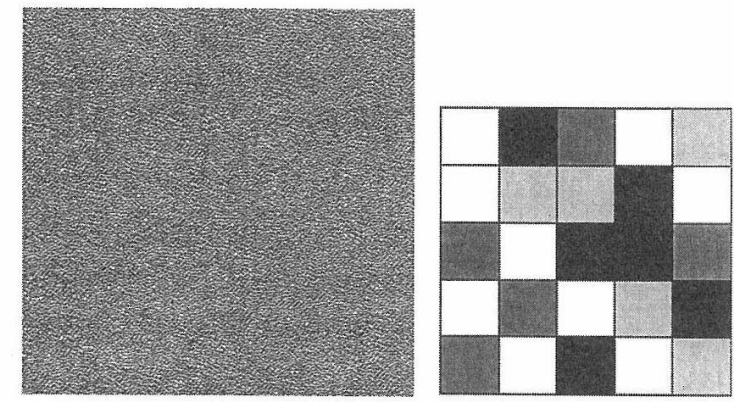

Fig. 9. (a) 4 phase level CGH pattern $(512 \times 512$ pixels, pixel size $10 \times 10 \mu \mathrm{m})$, (b) enlarged illustration of any points.
ルの合成 CGH を示す。この合成 CGH は，4レベルの濃 淡によって表されたものである。次に，この濃淡によっ て表された CGH をレジストに転写するため，4段の高さ を有するレリーフ構造の作製を行った。この 4 段の高さ は，ネガ型レジストの特徴を活かして，描画，現像後， 最上段のレベル 4 が初期膜厚 $\left(d_{0}\right)$, レベル 3 は $2 / 3 d_{0}$, レベル 2 は $1 / 3 d_{0}$, レベル 1 は 0 であるここで, レジ ストの初期膜厚 $\left(d_{0}\right)$ は，作製した CGH He-Neレー ザー（波長 $\lambda: 0.63 \mu \mathrm{m} ） て ゙$ 再生することを考虑に入れ， 次式で算出した。

$$
d_{0}=\frac{\lambda}{n-1} \times \frac{L-1}{L}
$$

$(n:$ 屈折率, $L:$ レベル数)

PMVS の屈折率 $(n)$ 䘮 1.41 , レベル数 $(L)$ を 4 とする と, $d_{0}$ は, $1.2 \mu \mathrm{m}$ となる。

次に，4段のレリーフ型ホログラムを得るために，各 ピクセルごとに照射するドーズ量の評価をおこなった。 Fig. 6 の規格化膜厚で，1，0.67，0.34，0になるドーズ 量を各ピクセルごとに照射すれば，4段のレリーフ型ホ ログラムが得られるのではなく，ピクセルごとに電子線 を照射したときに隣接するピクセルに影響を与える大き さ（近接効果の補正）を考慮する必要がある。この近接 效果の補正は「ドーズ変調法」によって行い，最適な電 子線照射量を測定した。その結果, 合成 $\mathrm{CGH}$ パターンに 一致するように，各ピクセルに電子線照射量を $2.50,1.07$, $0.59,0 \mu \mathrm{C} / \mathrm{cm}^{2}$ と変調させ描画, 現像を行うことで, 初 めて 4 段のレリーフ型ホログラムが得られた (Fig. 10)。 なお，このCGH を作製するための描画時間は，PMVS

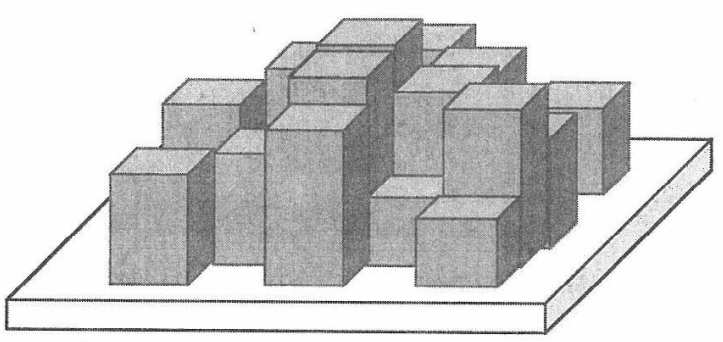

Fig. 10. CGH relief pattern derived from sensitivity curve of PMVS and proximity effect correction. Level 4 (highest part), Level 3, Level 2, Level 1 (nothing part) were fabricated at $2.50,1.07,0.59,0 \mu \mathrm{C} / \mathrm{cm}^{2}$. This illustration is equivalent to Fig 9 (b).

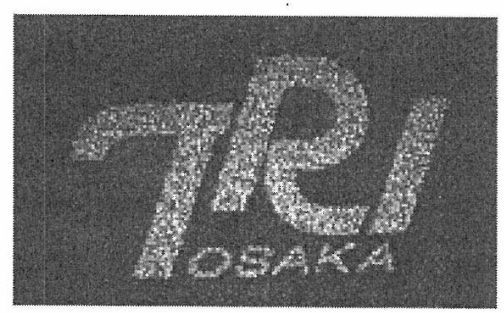

Fig. 11. Reconstructed image captured by CCD camera when the fabricated CGH is illuminated with an He-Ne laser. 
が電子線に対して感度が高いため, 約 30 分であった（他 のレジストでは 1 日かかることもある). 得られた CGH に He-Ne レーザ光を照射すると，Fig. 11 のように良好 な再生像を得ることができた。

$$
4 \text { ま と め }
$$

本研究では, ポリシロキサンの電子線レジストとしての 特性を調べた。その結果, ポリシロキサンは, 従来使用 されている電子線レジスト PMMAよりも 2 けた程度高感 度であった。 また, 現像結果は, 電子線リソグラフィー プロセスにおいて重要なプリベーク温度や現像時間には ほとんど依存しなかった。このことは, ポリシロキサン は，実際に使用する上で使いやすい電子線レジストであ ることを示している. 今後, ポリシロキサンの主鎖や側 鎖を修飾することによって, ポリシロキサンの物性（特 に，ガラス転移点）を向上させ，電子線レジストとして 重要なファクターである $\gamma$ 值（コントラスト）の向上を 図れば，汎用性の高いレジストとして利用できる。

本研究は, 大阪府試験研究機関提案型調査研究事業 「マイクロオプティクス素子作製用レジスト創製に関する 研究」と大阪府地域結集型共同研究事業「テラ光情報基
盤技術開発」で行われたものである．関係各位に感謝の 意を表します。また, CGH 設計をお願いしました大阪科 学技術センター 余 万吉博士に感謝致します.

\section{参 考 文 献}

1) L. Laakkonen, J. Lautanen, V. Kettunen and J. Turunen, J. Mod. Optics, 46, 1295 (1999)，塩野照弘；応用物理, 68, 633 (1999), (社) 応用物理学会日本光学会光設計研究グルー プ, “回折光学素子入門”, p.11（1997）オプトロニクス社.

2) W. H. Wong and E. Y. B. Pun, J. Vac. Sci. Technol., B19, 732 (2001).

3) http://www. nnf.cornell.edu/SPIEBook/spie7.htm.

4 ) A. S. Gozdz, H. G. Craighead and M. J. Bowden, Polym. Eng. Sci, 26, 1123 (1986).

5) http://www.njima.elec.keio.ac.jp/homepage/Window/ honda_10.html.

6) 日本化学会編, “新実験化学講座, 29 巻, 高分子材料”, p.205（1993）丸善.

7) W. Yu, K. Takahara, T. Konishi, T. Yotsuya and Y. Ichioka, Appl. Opt., 39, 3531 (2000). 